\title{
Occurrence and Detection of the DMI Resistance-Associated Genetic Element 'Mona' in Monilinia fructicola
}

Chao-Xi Luo, Department of Entomology, Soils, and Plant Sciences, Clemson University, Clemson, SC 29634; Kerik D. Cox, Department of Plant Pathology, Cornell University, New York State Agricultural Experiment Station, Geneva, NY 14456; and Achour Amiri and Guido Schnabel, Department of Entomology, Soils, and Plant Sciences, Clemson University, Clemson, SC 29634

\begin{abstract}
Luo, C.-X., Cox, K. D., Amiri, A., and Schnabel, G. 2008. Occurrence and detection of the DMI resistance-associated genetic element 'Mona' in Monilinia fructicola. Plant Dis. 92:1099-1103.

Sterol demethylation inhibitor (DMI) fungicide resistance in isolates of Monilinia fructicola from Georgia has been linked to overexpression of the MfCYP51 gene and a corresponding 65bp genetic element 'Mona' inserted in the upstream region of MfCYP51. In this study, a polymerase chain reaction-restriction fragment length polymorphism (PCR-RFLP) method was developed to detect the Mona element. Fourteen DMI fungicide-resistant (DMI-R) and six DMI fungicide-sensitive (DMI-S) isolates from Georgia, six DMI-R and 11 DMI-S isolates from South Carolina, seven DMI-R and nine DMI-S isolates from New York, and two DMI-R and three DMI-S isolates from Ohio were used in this study. The isolates from the southeastern United States and Ohio were collected from peach, whereas isolates from New York were collected from cherry. A 376-bp fragment containing the Mona element was consistently amplified with primer pair INS65-F and INS65-R from DMI-R isolates, and either a 311-bp or 1,815-bp fragment was amplified from DMI-S isolates. The primer pair did not amplify DNA fragments of similar sizes from isolates of five other common fruit rot pathogens of peach, including Alternaria alternata, Colletotrichum acutatum, Gilbertella persicaria, Penicillium expansum, and Rhizopus stolonifer. Gel electrophoresis of the PCR amplicon can distinguish between DMI-R and DMI-S isolates based on the 65-bp size difference of the amplicon; however, the restriction digestion assay can verify questionable results, especially in the absence of a positive control. Only the 376-bp fragment containing the Mona element was digestable with endonuclease $B s r \mathrm{BI}$, resulting in two restriction fragments of 236 and $140 \mathrm{bp}$ in size. In this study, a protocol for Mona detection from aerial fungal structures was developed that can yield results within a few hours of sampling. This study confirms that the Mona element is strongly linked to the DMI-resistance phenotype and reveals that overexpression of the MfCYP51 gene is a common DMI fungicide resistance mechanism in M. fructicola, not only in Georgia but throughout the eastern United States.
\end{abstract}

Additional keywords: brown rot, molecular markers, propiconazole, stone fruits

Sterol demethylation inhibitor (DMI) fungicides have been widely used for more than 20 years to control brown rot of stone fruits caused by Monilinia spp. As a result, resistance to DMI fungicides was detected in $M$. fructicola isolates from commercial peach orchards in Georgia (12), and more recently from commercial cherry orchards in New York (10). DMI fungicide resistance was suspected in M. fructicola from commercial peach orchards in Ohio (K. Cox \& M. Ellis, personal communication).

Corresponding author: G. Schnabel

E-mail: schnabe@clemson.edu

Technical contribution no. 5374 of the Clemson University Experiment Station. This material is based upon work supported by USDA CSREES under project number SC-1000642.

Accepted for publication 17 March 2008.

doi:10.1094/PDIS-92-7-1099

(C) 2008 The American Phytopathological Society sion was associated with a repetitive genetic element called 'Mona' located upstream of the MfCYP51 gene. The Mona element contains a predicted promoter sequence, which likely triggers the elevated expression of MfCYP51 (8).

The goal of this study was to develop a molecular assay to quickly identify the Mona element located upstream from MfCYP51 in M. fructicola and to screen a larger collection of isolates from the eastern United States with varying DMI resistance phenotypes.

\section{MATERIALS AND METHODS}

Isolates. A total of 58 single-spore $M$. fructicola isolates resistant (DMI-R) or sensitive (DMI-S) to propiconazole were used in this study (Table 1). These isolates were collected from 10 locations in 10 counties of four states including Georgia, South Carolina, New York, and Ohio. Whenever possible, DMI-R and DMI-S isolates were included from the same location to ensure similar genetic backgrounds. Isolates from South Carolina, Georgia, and Ohio were collected from peach fruit, whereas isolates from New York were collected from cherry fruit as described previously (12). All isolates were kept on potato dextrose agar (PDA; EMD Chemicals, Gibbstown, NJ) slants at $4^{\circ} \mathrm{C}$ under sterile mineral oil. In addition to M. fructicola, five other common fruit pathogens (Alternaria alternata, Colletotrichum acutatum, Gilbertella persicaria, Penicillium expansum, and Rhizopus stolonifer) were included. These isolates were obtained from either commercial or experimental orchards in South Carolina and Georgia.

Sensitivity of $M$. fructicola isolates to propiconazole. The sensitivity of the $M$. fructicola isolates to the DMI fungicide propiconazole (PropiMax EC; Dow AgroSciences LLC, Indianapolis, IN) was determined, as previously described (1). The relative mycelial growth was expressed as the growth on $0.3 \mu \mathrm{g} / \mathrm{ml}$ propiconazoleamended PDA as a percentage of the growth on nonamended PDA. The discriminatory dose of $0.3 \mu \mathrm{g} / \mathrm{ml}$ was shown previously to distinguish between baseline (sensitive) and resistant populations of $M$. fructicola (1).

Extraction of genomic DNA. Each fungal isolate was grown in $40 \mathrm{ml}$ of potato 
dextrose broth (PDB; Difco Laboratories, Sparks, MD) for 5 days at $22^{\circ} \mathrm{C}$ on an orbital shaker (120 rpm). Mycelium was harvested, frozen in liquid nitrogen, and ground into fine powder with mortar and pestle. Genomic DNA was isolated from the powdered mycelium using the DNeasy
Plant Mini Kit (Qiagen Inc., Valencia, CA) according to the manufacturer's manual.

Development of a PCR-based method to detect the Mona element located upstream of MfCYP51 and validation of primer specificity. PCR primers INS65-F (5'-TCG ATG TTG CGT GGT CTG TCA- $\left.3^{\prime}\right)$ and INS65-R (5'-CGG AGA GCG TCG ATG TAG GTG-3') were designed using the software DNASTAR (DNASTAR Inc., Nevada City, CA) based on a previously cloned MfCYP51 upstream sequence (GenBank accession number EU035301). PCR reaction volumes were $25 \mu \mathrm{l}$ contain-

Table 1. Characteristics of Monilinia fructicola isolates from Georgia, South Carolina, New York, and Ohio, and results of polymerase chain reaction (PCR) amplification and restriction digestion of a portion of the MfCYP51 gene upstream sequence

\begin{tabular}{|c|c|c|c|c|c|c|}
\hline Isolate & Origin & Host & $\begin{array}{c}\text { Year of } \\
\text { isolation }\end{array}$ & $\begin{array}{l}\text { Sensitivity } \\
\text { phenotype }^{a}\end{array}$ & $\begin{array}{l}\text { PCR fragment } \\
\text { size }(\mathbf{b p})^{\mathbf{b}}\end{array}$ & $\begin{array}{c}B s r \mathrm{BI} \\
\text { restriction site }\end{array}$ \\
\hline Bmpc7 & Byron, GA & Peach & 2006 & $\mathrm{R}(29.7)$ & 376 & + \\
\hline Bmpc10 & Byron, GA & Peach & 2006 & $\mathrm{R}(30.8)$ & 376 & + \\
\hline Bmpc13 & Byron, GA & Peach & 2006 & $\mathrm{R}(29.5)$ & 376 & + \\
\hline BGA7 & Byron, GA & Peach & 2004 & $\mathrm{R}(49.7)$ & 376 & + \\
\hline BGA17 & Byron, GA & Peach & 2004 & $\mathrm{R}(45.0)$ & 376 & + \\
\hline BGA25 & Byron, GA & Peach & 2004 & $S(2.6)$ & 311 & - \\
\hline GADL7 & Fort Valley, GA & Peach & 2003 & R (38.7) & 376 & + \\
\hline GADL129 & Fort Valley, GA & Peach & 2003 & $R(55.6)$ & 376 & + \\
\hline GADL133 & Fort Valley, GA & Peach & 2003 & $\mathrm{R}(58.8)$ & 376 & + \\
\hline GADL193 & Fort Valley, GA & Peach & 2003 & $\mathrm{R}(35.0)$ & 376 & + \\
\hline GADL3 & Fort Valley, GA & Peach & 2003 & $\mathrm{~S}(0.0)$ & 311 & - \\
\hline GADL161 & Fort Valley, GA & Peach & 2003 & $S(3.7)$ & 311 & - \\
\hline GAAP3 & Macon, GA & Peach & 2003 & R (47.9) & 376 & + \\
\hline GAAP4 & Macon, GA & Peach & 2003 & $\mathrm{R}(28.7)$ & 376 & + \\
\hline GAAP5 & Macon, GA & Peach & 2003 & $\mathrm{R}(36.3)$ & 376 & + \\
\hline GAAP6 & Macon, GA & Peach & 2003 & $\mathrm{R}(21.8)$ & 376 & + \\
\hline GAAP10 & Macon, GA & Peach & 2003 & $\mathrm{R}(37.4)$ & 376 & + \\
\hline GAAP11 & Macon, GA & Peach & 2003 & $\mathrm{~S}(0.0)$ & 311 & - \\
\hline GAAP12 & Macon, GA & Peach & 2003 & $\mathrm{~S}(0.0)$ & 311 & - \\
\hline GAAP33 & Macon, GA & Peach & 2003 & $\mathrm{~S}(13.7)$ & 311 & - \\
\hline SCEG5 & Edgefield, SC & Peach & 2007 & $\mathrm{R}(70.6)$ & 376 & + \\
\hline SCEG6 & Edgefield, SC & Peach & 2007 & $R(68.6)$ & 376 & + \\
\hline SCEG9 & Edgefield, SC & Peach & 2007 & $\mathrm{R}(46.1)$ & 376 & + \\
\hline SCEG11 & Edgefield, SC & Peach & 2007 & $\mathrm{R}(70.6)$ & 376 & + \\
\hline SCEG12 & Edgefield, SC & Peach & 2007 & $\mathrm{R}(74.5)$ & 376 & + \\
\hline SCEG13 & Edgefield, SC & Peach & 2007 & $\mathrm{R}(47.1)$ & 376 & + \\
\hline SC99A3 & Edgefield, SC & Peach & 2004 & $\mathrm{~S}(5.0)$ & 311 & - \\
\hline SC99A4 & Edgefield, SC & Peach & 2004 & $\mathrm{~S}(1.3)$ & 311 & - \\
\hline SCBS1 & York, SC & Peach & 2003 & $\mathrm{~S}(0.9)$ & 311 & - \\
\hline SCBS2 & York, SC & Peach & 2003 & $\mathrm{~S}(7.1)$ & 311 & - \\
\hline SCBS7 & York, SC & Peach & 2003 & $S(0.7)$ & 311 & - \\
\hline SCBS14 & York, SC & Peach & 2003 & S (17.6) & 311 & - \\
\hline SCCC8 & Saluda, SC & Peach & 2003 & $S(0.0)$ & 311 & - \\
\hline SCCC12 & Saluda, SC & Peach & 2003 & $\mathrm{~S}(0.0)$ & 311 & - \\
\hline SCDL21 & Anderson, SC & Peach & 2001 & $\mathrm{~S}(5.1)$ & 311 & - \\
\hline SCDL28 & Anderson, SC & Peach & 2001 & $S(0.6)$ & 311 & - \\
\hline SCDL72 & Anderson, SC & Peach & 2001 & $\mathrm{~S}(3.1)$ & 311 & - \\
\hline NY1A & Geneva, NY & Cherry & 2007 & $\mathrm{R}(48.1)$ & 376 & + \\
\hline NY1C & Geneva, NY & Cherry & 2007 & $\mathrm{R}(40.6)$ & 376 & + \\
\hline NY2F & Geneva, NY & Cherry & 2007 & R (31.9) & 376 & + \\
\hline NY4B & Geneva, NY & Cherry & 2007 & $\mathrm{R}(55.5)$ & 376 & + \\
\hline NY4C & Geneva, NY & Cherry & 2007 & $\mathrm{R}(50.7)$ & 376 & + \\
\hline NY6B & Geneva, NY & Cherry & 2007 & $\mathrm{R}(46.2)$ & 376 & + \\
\hline NY6C & Geneva, NY & Cherry & 2007 & $\mathrm{R}(34.7)$ & 376 & + \\
\hline NY3B & Geneva, NY & Cherry & 2007 & S (1.6) & 1,815 & - \\
\hline NY3C & Geneva, NY & Cherry & 2007 & $\mathrm{~S}(6.8)$ & 1,815 & - \\
\hline NY7B & Geneva, NY & Cherry & 2007 & $S(7.2)$ & 1,815 & - \\
\hline NY7C & Geneva, NY & Cherry & 2007 & $\mathrm{~S}(3.9)$ & 1,815 & - \\
\hline NY8C & Geneva, NY & Cherry & 2007 & $\mathrm{~S}(9.2)$ & 311 & - \\
\hline NY9C & Geneva, NY & Cherry & 2007 & $\mathrm{~S}(3.5)$ & 1,815 & - \\
\hline NY10B & Geneva, NY & Cherry & 2007 & $\mathrm{~S}(0.7)$ & 1,815 & - \\
\hline NY12B & Geneva, NY & Cherry & 2007 & $\mathrm{~S}(8.9)$ & 1,815 & - \\
\hline NY13B & Geneva, NY & Cherry & 2007 & $S(2.6)$ & 1,815 & - \\
\hline $\mathrm{OH} 1 \mathrm{P}$ & Berlin Heights, $\mathrm{OH}$ & Peach & 2006 & $\mathrm{R}(41.8)$ & 376 & + \\
\hline OH3P & Berlin Heights, $\mathrm{OH}$ & Peach & 2006 & $\mathrm{~S}(3.8)$ & 311 & - \\
\hline OH8P & Rittman, $\mathrm{OH}$ & Peach & 2006 & $\mathrm{R}(37.8)$ & 376 & + \\
\hline OH6P & Rittman, $\mathrm{OH}$ & Peach & 2006 & $S(0.6)$ & 311 & - \\
\hline $\mathrm{OH} 10 \mathrm{P}$ & Rittman, $\mathrm{OH}$ & Peach & 2006 & $S(9.6)$ & 311 & - \\
\hline
\end{tabular}

a An isolate was considered resistant $(\mathrm{R})$ when the mycelial growth was equal to or greater than $20 \%$ at the discriminatory dose of $0.3 \mu \mathrm{g} / \mathrm{ml}$ propiconazole relative to growth on nonamended medium; all other isolates were considered sensitive (S). Relative growth at $0.3 \mu \mathrm{g} / \mathrm{ml}$ propiconazole is shown in parentheses.

b PCR fragment was amplified from genomic DNA using primers INS65-F and INS65-R.

c "+" or "-" indicates presence or absence of the BsrBI restriction site within the 376-bp PCR fragment, respectively. 
ing $1 \times$ PCR buffer provided by the manufacturer, $20 \mathrm{ng}$ genomic DNA, $0.5 \mu \mathrm{M}$ of each primer, $200 \mu \mathrm{M}$ of each dNTP, and 0.625 unit of Taq DNA polymerase (New England BioLabs, Ipswich, MA). Amplifications were performed in an "iCycler" thermal cycler (Bio-Rad Laboratories Inc., Hercules, CA) programmed for $3 \mathrm{~min}$ at $94^{\circ} \mathrm{C}, 30$ cycles of $1 \mathrm{~min}$ at $94^{\circ} \mathrm{C}, 1 \mathrm{~min}$ at $60^{\circ} \mathrm{C}, 1 \mathrm{~min}$ at $72^{\circ} \mathrm{C}$, followed by a final extension step of $5 \mathrm{~min}$ at $72^{\circ} \mathrm{C}$. The PCR products were separated on a $2.0 \%$ agarose gel in $0.5 \times$ TBE buffer $(44.5 \mathrm{mM}$ Trisborate, $1 \mathrm{mM}$ EDTA, $\mathrm{pH} 8.0$ ) at $100 \mathrm{~V}$ for $1 \mathrm{~h}$. Gels were photographed with an Electrophoresis Documentation and Analysis System (KODAK EDAS 290, Eastman Kodak Company, New Haven, CT).

Amplification of the expected DNA fragments was confirmed by sequencing the fragments from seven DMI-R and three DMI-S isolates from Georgia, three DMI$\mathrm{R}$ and three DMI-S isolates from South Carolina, one DMI-R and four DMI-S isolates from New York, and two DMI-R and two DMI-S isolates from Ohio. PCR products were purified using the QiaQuick Gel Extraction Kit (Qiagen Inc., Valencia, CA) and subsequently sequenced with BigDye Terminator v3.1 Kit (Applied BioSystems Inc., Foster City, CA) using primers INS65-F and INS65-R. All sequencing reactions were performed at the Clemson University Genomics Institute (CUGI).

The specificity of this primer pair to $M$. fructicola DNA was also examined on two isolates from each of five fungal species causing peach rots: A. alternata, C. acutatum, G. persicaria, $P$. expansum, and $R$. stolonifer. PCR amplification and gel electrophoresis analysis was conducted as described above.

Restriction fragment length polymorphism (RFLP) analysis of the PCR fragment amplified with primers INS65-F and INS65-R. A single BsrBI (New England BioLabs) restriction site was identified within the Mona element using the software DNAssist version 2.0 (DNAssist cc, Bellville, South Africa). PCR fragments were purified with the QiaQuick Gel Extraction Kit (Qiagen), and restriction digestions were performed at $37^{\circ} \mathrm{C}$ for $16 \mathrm{~h}$ according to the manufacturer's recommendations (New England BioLabs). Both undigested and digested PCR products were separated on a $2.0 \%$ agarose gel, and the gel was photographed as described above.

To investigate whether the RFLP analysis could be simplified, the unpurified PCR fragment from DMI-R isolate GADL7 was digested with shortened incubation times. Digestions were conducted at $37^{\circ} \mathrm{C}$ for $0,0.5,1,2,4$, and $16 \mathrm{~h}$ in 20- $\mu \mathrm{l}$ digestion volume including $2 \mu \mathrm{l}$ of $10 \times$ NEBuffer 2 provided by the manufacturer, $0.5 \mu \mathrm{l}$ of $\mathrm{BsrBI}$ enzyme (5 unit/reaction), and $17.5 \mu \mathrm{l}$ of fresh PCR product. After the designated digestion time, BsrBI was inactivated by adding 0.5 $\mu \mathrm{l}$ of $0.5 \mathrm{M}$ EDTA, followed by heat inactivation at $80^{\circ} \mathrm{C}$ for $20 \mathrm{~min}$. The digested PCR fragments were separated on a $2.0 \%$ agarose gel and photographed as described above.

Potential adaptation of this RFLP analysis to field samples was investigated using aerial fungal structures from isolates growing on agar medium and peach fruit. Aerial fungal structures ( 1 to $5 \mathrm{mg}$; mainly mycelium and conidia) from $39 \mathrm{NY}$ cherry $M$. fructicola isolates (NY1-13A-C) growing on PDA or artificially inoculated cherries (isolates NY1A, $-1 \mathrm{C},-8 \mathrm{~B}$, and $-8 \mathrm{C}$ ) and four SC peach isolates (SCEG.5, -6, -9, and SC99A3) growing on artificially inoculated peach fruit (12) were removed without touching either the PDA or the peach fruit tissue using sterile toothpicks. Structures were placed into sterile $0.2 \mathrm{ml}$ PCR tubes containing $5 \mu \mathrm{l}$ of the Lyse-NGO PCR Reagent (Pierce, Rockford, IL). Samples were then processed according to the manufacturer's instructions, and subsequent PCR-RFLP analysis for detection of Mona was performed as described above. The digested PCR fragments were separated on a $2.0 \%$ agarose gel for $1 \mathrm{~h}$ at 100 $\mathrm{V}$ and photographed.

\section{RESULTS}

Sensitivity of $M$. fructicola isolates to propiconazole. Isolates resistant to the DMI fungicide propiconazole were collected from three locations in Georgia (Byron, Fort Valley, and Macon), one location in South Carolina (Edgefield), one location in New York (Geneva), and two locations in Ohio (Berlin Heights and Rittman). These locations were chosen be- cause brown rot developed on fruit despite proper preharvest application of DMI fungicides. Relative growth values for resistant isolates at the discriminatory dose of $0.3 \mu \mathrm{g} / \mathrm{ml}$ propiconazole ranged from 21.8 to $74.5 \%$ (Table 1). DMI-S isolates were included from each of these locations and from three additional locations in South Carolina where DMI-R isolates have not yet been identified. Relative growth of the DMI-S isolates at the discriminatory dose of $0.3 \mu \mathrm{g} / \mathrm{ml}$ propiconazole ranged from 0 to $17.6 \%$ (Table 1 ).

Development of a PCR-based method to detect the Mona element located upstream of MfCYP51 and validation of primer specificity. The primer pair INS65$F$ and INS65-R was designed based on the flanking sequence (GenBank accession number EU035301) of the Mona element located upstream of MfCYP51. The primers amplified a 376-bp fragment from all DMI-R isolates regardless of their origin and a 311-bp fragment from most DMI-S isolates (Table 1; Fig. 1). Except for the isolate $\mathrm{NY} 8 \mathrm{C}$, the primer pair amplified a single 1,815-bp fragment from all DMI-S cherry isolates from New York (Table1; Fig. 1). Sequencing the 1,815-bp fragment from three representative isolates revealed that it contained an insert 1,504 bp in length. However, no portion of the sequence was homologous to the Mona element (data not shown). The primer pair did not amplify DNA of the relevant sizes from two isolates of each of five other common stone fruit pathogens. We did notice, however, weak PCR amplification of an approximate 1,500-bp product from the DNA of two $P$. expansum isolates (Fig. 2). This fragment, however, was not

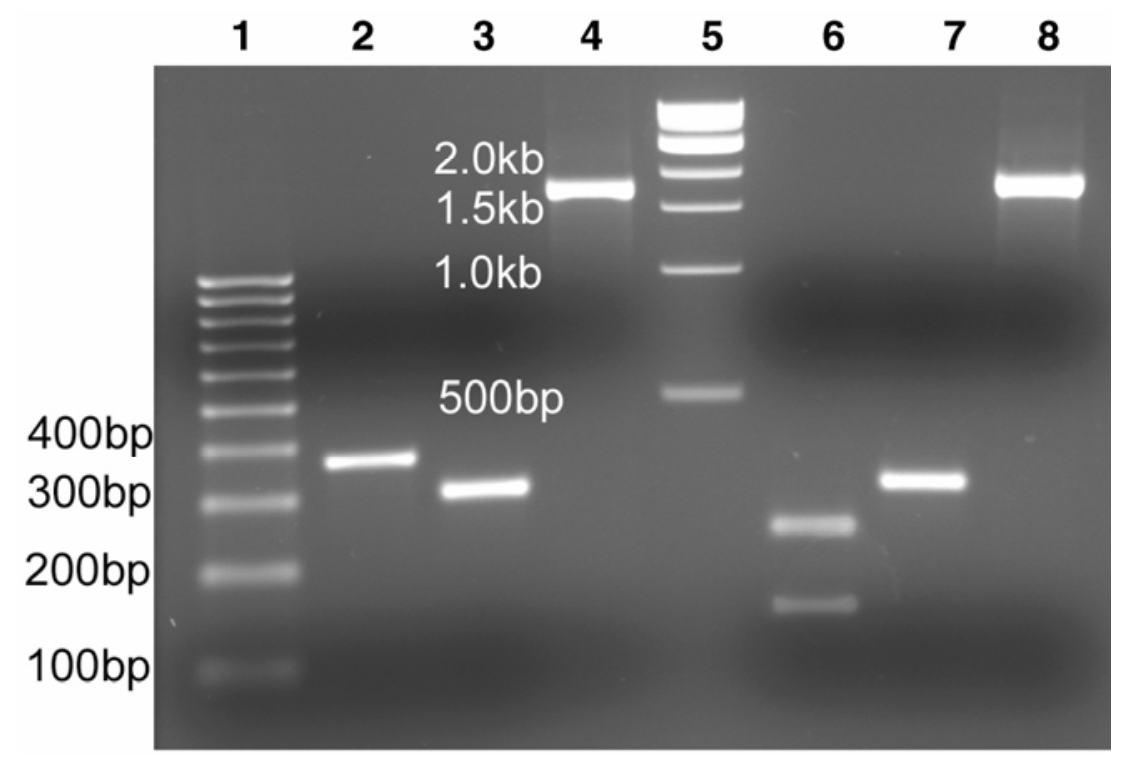

Fig. 1. Gel electrophoresis analysis of undigested and $B s r \mathrm{BI}$ digested polymerase chain reaction (PCR) fragments amplified from Monilinia fructicola DMI-R and DMI-S isolates with primers INS65-F and INS65-R. Lanes 1 and 5, EZ load 100-bp molecular ruler (Bio-Rad Laboratories) and Quick Load $1 \mathrm{~kb}$ DNA Ladder (New England BioLabs), respectively; lanes 2 to 4, undigested PCR fragments from DMI-R isolate NY2F, and DMI-S isolates OH3P and NY3C; lanes 6 to $8, B s r$ BI digested PCR fragments from DMI-R NY2F, and DMI-S isolates OH3P and NY3C. 


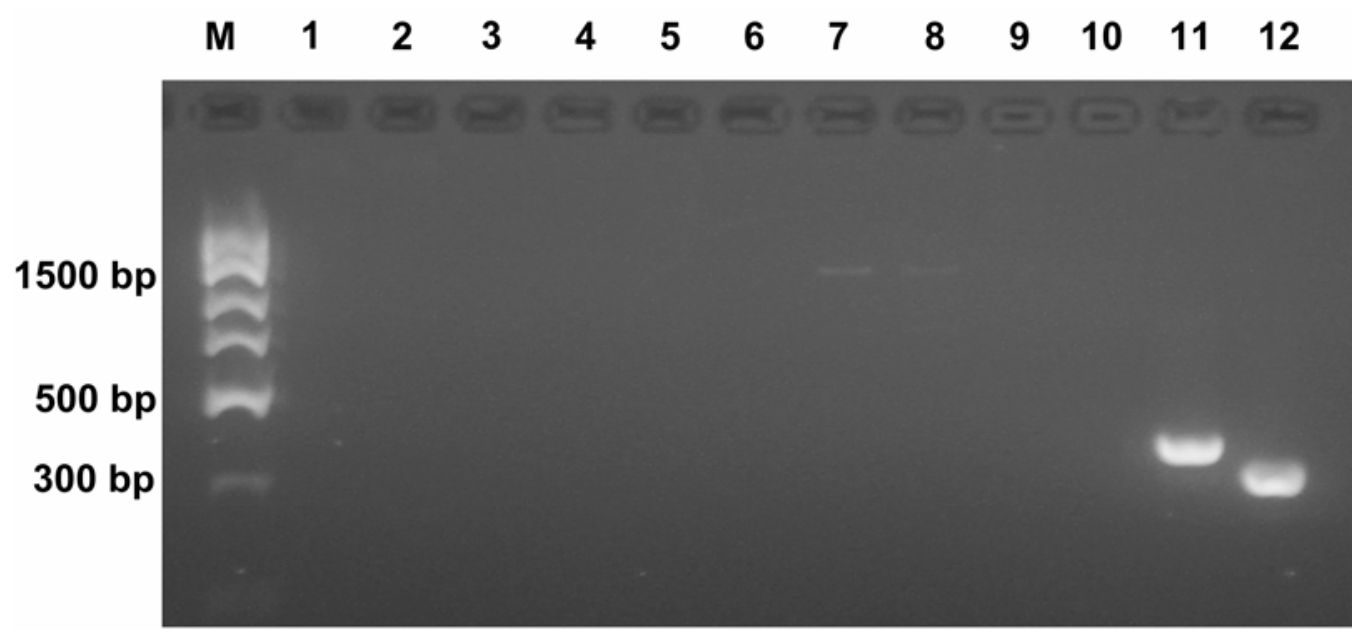

Fig. 2. Gel electrophoresis analysis of polymerase chain reaction (PCR) fragments from six fungi using primers $I N S 65-F$ and $I N S 65-R$. M = exACTGene Low Range DNA Ladder (Fisher Scientific); lanes 1 and 2, Alternaria alternata isolates 1 and 2; lanes 3 and 4 , Colletotrichum acutatum isolates 1 and 2; lanes 5 and 6, Gilbertella persicaria isolates 1 and 2; lanes 7 and 8, Penicillium expansum isolates 1 and 2; lanes 9 and 10, Rhizopus stolonifer, isolates 1 and 2; and lanes 11 and 12, Monilinia fructicola isolates GADL7 (DMI-R) and GAAP11 (DMI-S).

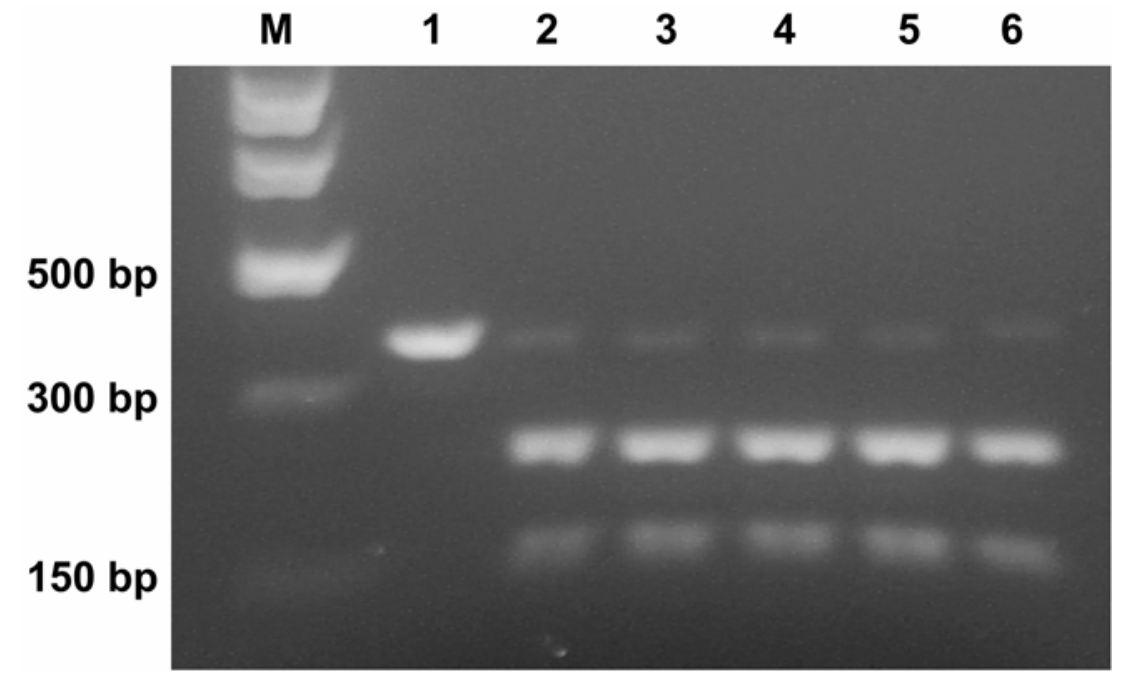

Fig. 3. Gel electrophoresis analysis of undigested and BsrBI digested polymerase chain reaction (PCR) fragments amplified from Monilinia fructicola isolate GADL7 with primers INS65-F and INS65-R. M $=$ exACTGene Low Range DNA Ladder (Fisher Scientific); lane 1, undigested PCR fragment; lanes 2 to 6 , restriction digests after $0.5,1,2,4$, and $16 \mathrm{~h}$ of incubation at $37^{\circ} \mathrm{C}$, respectively. Digestion was terminated by adding $12.5 \mathrm{mM}$ EDTA followed by a 20 -min heat inactivation at $80^{\circ} \mathrm{C}$.

digestible with restriction enzyme $B s r$ BI (data not shown). One representative sequence $(1,815 \mathrm{bp})$ containing the newly discovered 1,504-bp insertion from DMI-S New York isolate NY3B was submitted to GenBank (accession number EU257287).

RFLP analysis of the PCR fragment amplified with primers INS65-F and INS65-R. BsrBI digestion of the 376-bp PCR fragment generated two restriction fragments of $236 \mathrm{bp}$ and $140 \mathrm{bp}$ in size. Neither the 311-bp nor the 1,815-bp PCR fragment was BsrBI-digestible (Table 1; Fig. 1). Efforts to facilitate and shorten the RFLP analysis revealed that the PCR product did not require a purification step prior to endonuclease restriction digestion (data not shown). Also, shortening the incubation time from the manufacturer's recommendation of $16 \mathrm{~h}$ to $0.5 \mathrm{~h}$ did not result in a noticable compromise in digestion activity (Fig. 3).
PCR-RFLP analysis was successfully performed using the Lyse-N-GO PCR Reagent (Pierce) with aerial fungal structures obtained from $M$. fructicola cultures and from inoculated fruit as PCR template (Fig. 4). Of the $39 \mathrm{NY}$ cherry isolates grown on PDA, the use of Lyse-NGO PCR Reagent yielded results 37 times on the first attempt $(94.87 \%$ success rate; data not shown). Results were obtained for the remaining two isolates on a subsequent attempt (data not shown). Likewise, successful amplifications and restriction digestions were conducted when fungal structures were taken directly from inoculated peach fruit (data not shown).

\section{DISCUSSION}

Both point mutations in and the overexpression of the cytochrome P450 lanosterol 14- $\alpha$ demethylase (CYP51) gene have been linked to DMI fungicide resis- tance in plant pathogenic fungi. While point mutations are generally easy to detect with PCR-based molecular techniques $(2,3)$, the detection of CYP51 overexpression may require a more expensive and elaborate effort such as real-time PCR or northern blot analysis. However, in some plant pathogenic fungi, overexpression is linked to inserts upstream of the CYP51 gene, which can be used as molecular markers for rapid, PCR-based detection. For example, overexpression of the CYP51 gene from $P$. digitatum was linked to inserts upstream of CYP51, which allowed the development of quick PCR-based detection methods $(4,5)$. Similar inserts were found in isolates of Venturia inaequalis and Blumeriella jaapii resistant to myclobutanil (13) and fenbuconazole (9), respectively, and PCR-based methods were developed for their identification $(11,13)$.

In this study, we developed a PCR-based assay that distinguishes reliably between M. fructicola isolates possessing or lacking the Mona element linked to the DMI-resistance phenotype. The primer pair INS65-F and INS65-R did not amplify DNA fragments of similar sizes from five other common peach fruit pathogens. This result emphasizes the specificity of this primer pair to the targeted $M$. fructicola DNA However, the 311-bp and the 376-bp fragments obtained from sensitive and resistant isolates, respectively, may not be easily distinguished on low percentage agarose gels, especially if positive controls are not available. Therefore, the presence or absence of the Mona element in the amplification product can be confirmed by digesting the PCR product with the restriction endonuclease $B s r \mathrm{BI}$; only fragments containing the Mona element were digestible with this enzyme. The amplification of a 1,815-bp fragment in DMI-S cherry isolates was somewhat unexpected. However, the fragment neither contained the Mona element nor was digestible by the BsrBI 


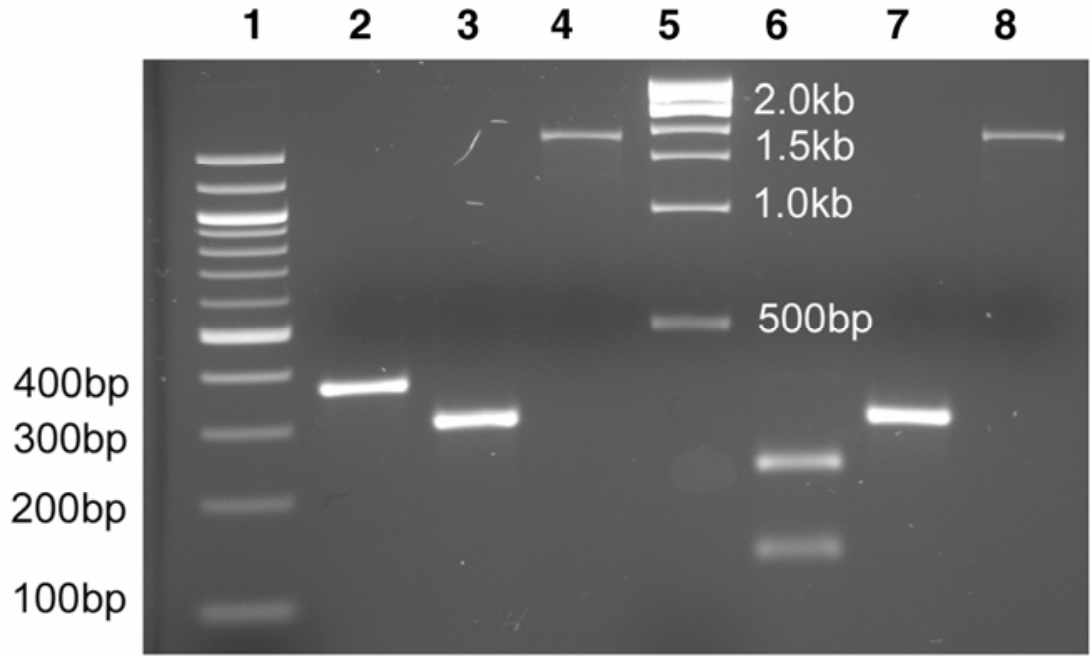

Fig. 4. Gel electrophoresis analysis of undigested and $B s r \mathrm{BI}$ digested polymerase chain reaction (PCR) fragments amplified directly from aerial fungal structures of Monilinia fructicola DMI-R and DMI-S isolates with primers INS65-F and INS65-R using the Lyse-N-GO PCR Reagent (Pierce) for template preparation. Lanes 1 and 5, Quick Load 100-bp Molecular Ladder (New England Biolabs) and Quick Load $1 \mathrm{~kb}$ DNA Ladder (New England BioLabs), respectively; lanes 2 to 4, undigested PCR fragments from DMI-R isolate NY2F, and DMI-S isolates NY8C and NY3C; lanes 6 to 8, BsrBI digested PCR fragments from DMI-R isolate NY2F, and DMI-S isolates NY8C and NY3C.

endonuclease. Also, the presence of a 1,504-bp insert within the 1,815-bp fragment did not correlate with the DMI resistance phenotype, indicating that it may not influence expression of the MfCYP51 gene.

The standard PCR-based protocol to detect Mona would normally take several days to conduct because it includes culturing the fungus to obtain sufficient biomass for DNA extraction, PCR amplification, purification of the PCR fragment, restriction digestion, and gel electrophoresis. We found that aerial fungal structures of $M$. fructicola obtained from agar medium and from symptomatic fruit (data not shown) can be used directly as PCR template when lysed in Lyse-N-GO PCR Reagent. We also determined that the PCR product does not need to be purified prior to restriction digestion with the enzyme $B s r \mathrm{BI}$, and that a 30-min restriction digestion is sufficient. Thus, within a few hours, the Mona element can be detected from fungal structures on a symptomatic fruit.

Results of this study confirm that overexpression of the MfCYP51 gene, as determined by the presence of the Mona element (8), is a common mechanism in conferring DMI resistance in M. fructicola in Georgia, South Carolina, New York, and Ohio. This is the first official report of reduced sensitivity to DMI fungicides in M. fructicola isolates from South Carolina and Ohio. So far, all DMI-R isolates we collected from the four aforementioned states contained the Mona element upstream of MfCYP51. This result is consistent with reports from Japan and California, where DMI resistance in $P$. digitatum was consistently linked to inserts upstream of the CYP51 gene $(4,5)$. Other studies have reported strong correlations between inserts and the resistance phenotype, but exceptions were reported where resistant isolates lacked an insert, indicating the existence of other resistance mechanisms (11).

Sequence analysis revealed that the nucleotide composition and the location of the Mona element were identical in isolates from South Carolina, Georgia, New York, and Ohio (data not shown). Therefore, it is likely that all DMI-R isolates derived from a common ancestor. It would therefore be fair to assume that DMI-R isolates are genetically closely related or even identical. In a previous study, DMI-R isolates from Georgia revealed identical nucleotide compositions of the MfCYP51 gene and the immediate MfCYP51 upstream region (including the Mona element), whereas DMI-S isolates collected from the same orchards revealed ample nucleotide variations in these regions (8). However, the same study showed genetic variability among DMI-R isolates as detected by microsatellite primer analysis and varying numbers of the Mona element in individual genomes. Based on these results, the authors hypothesized that the insertion event occurred before or shortly after the introduction of DMI fungicides in the 1970s and 1980s. The ubiquity of the Mona element in M. fructicola populations stretching from mid-Georgia to New York described in our study supports this hypothesis.

\section{ACKNOWLEDGMENTS}

We thank Michael A. Ellis for providing isolates from Ohio for this study. This material is based upon work supported by grants no. 2004-04014 of the USDA-CSREES RAMP (Risk Avoidance and
Mitigation) program and no. 2006-34103-17007 of the USDA S-RIPM program.

\section{LITERATURE CITED}

1. Cox, K. D., Bryson, P. K., and Schnabel, G. 2007. Instability of propiconazole resistance and fitness in Monilinia fructicola. Phytopathology 97:448-453.

2. Delye, C., Bousset, L., and Corio-Costet, M. F 1998. PCR cloning and detection of point mutations in the eburicol 14 a-demethylase (CYP51) gene from Erysiphe graminis f. sp. hordei, a "recalcitrant" fungus. Curr. Genet. 34:399-403

3. Delye, C., Laigret, F., and Corio-Costet, M.-F. 1997. Cloning and sequence analysis of the eburicol 14- $\alpha$ demethylase gene of the obligate biotrophic grape powdery mildew fungus. Gene 195:29-33.

4. Ghosoph, J. M., Schmidt, L. S., Margosan, D. A., and Smilanick, J. L. 2007. Imazalil resistance linked to a unique insert in the PdCYP5I promoter region of Penicillium digitatum Postharv. Biol. Technol. 44:9-18.

5. Hamamoto, H., Hasegawa, K., Nakaune, R., Lee, Y. J., Makizumi, Y., Akutsu, K., and Hibi, T. 2000 Tandem repeat of a transcriptional enhancer upstream of the sterol 14 alpha-demethylase gene (CYP51A1) in Penicillium digitatum. Appl. Environ. Microbiol. 66:3421-3426.

6. Lalancette, N., and Foster, K. A. 2001. Brown rot management on peach using Scala and Trilogy, 2000. Fungic. Nematicide Tests 56:STF4.

7. Lalancette, N., Foster, K. A., and Stoms, K. 2004. Management of peach diseases using mixtures and combinations of DMI and Qol fungicides, 2003. Fungic. Nematicide Tests 59:STF006.

8. Luo, C. X., and Schnabel, G. 2008. The cytochrome P450 lanosterol 14- $\alpha$ demethylase gene is a demethylation inhibitor fungicide resistance determinant in Monilinia fructicola field isolates from Georgia. Appl. Environ. Microbiol. 74:359-366

9. Ma, Z., Proffer, T. J., Jacobs, J. L., and Sundin, G. W. 2006. Overexpression of the 14a-demethylase target gene (cyp51) mediates fungicide resistance in Blumeriella jaapii. Appl. Environ. Microbiol. 72:2581-2585.

10. Parker, D. M., Zhang, N., Smart, C. D., and Koeller, W. D. 2006. Polymorphism of 14 alpha-demethylase gene (CYP51) in brown rot pathogen Monilinia fructicola from a resistant orchard in New York State. (Abstr.) Phytopathology 96:S90.

11. Proffer, T. J., Berardi, R., Ma, Z., Nugent, J. E., Ehret, G. R., McManus, P. S., Jones, A. L. and Sundin, G. W. 2006. Occurrence, distribution, and polymerase chain reaction-based detection of resistance to sterol demethylation inhibitor fungicides in populations of Blumeriella jaapii in Michigan. Phytopathology 96:709-717.

12. Schnabel, G., Bryson, P. K., Bridges, W. C., and Brannen, P. M. 2004. Reduced sensitivity in Monilinia fructicola to propiconazole in Georgia and implications for disease management. Plant Dis. 88:1000-1004.

13. Schnabel, G., and Jones, A. L. 2001. The $14 \alpha-$ demethylase (CYP51A1) gene is overexpressed in Venturia inaequalis strains resistant to myclobutanil. Phytopathology 91:102-110.

14. van den Bossche, H., Marichal, P., Gorrens, J., Bellens, D., Moereels, H., and Janssen, P. A. J. 1990. Mutation in cytochrome P450-dependent 14-alpha demethylase results in decreased affinity for azole antifungals. Biochem. Soc. Trans. 18:56-59.

15. Zehr, E. I., Toler, J. E., and Luszcz, L. A. 1991 Spread and persistence of benomyl-resistant Monilinia fructicola in South Carolina peach orchards. Plant Dis. 75:590-593. 